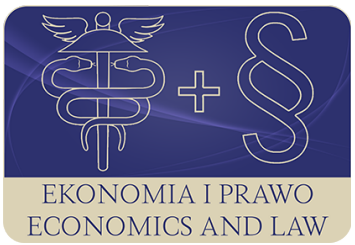

EKONOMIA I PRAWO. ECONOMICS AND LAW

Volume 17, Issue 2, June 2018

p-ISSN 1898-2255, e-ISSN 2392-1625

www.economicsandlaw.pl

ORIGINAL ARTICLE

received 13.06.2017; revised 20.03.2018; accepted 30.06.2018

Citation: Derlukiewicz, N., \& Mempel-Śnieżyk, A. (2018). European cities in the face of sustainable development. Ekonomia i Prawo. Ecomomics and Law, 17(2): 125-135. doi:10.12775/EiP.2018.009.

\title{
European cities in the face of sustainable development
}

\section{NIKI DERLUKIEWICZ}

corresponding author

Wroclaw University of Economics, Faculty of Economic Sciences, Department of Macroeconomics, ul. Komandorska 118/120, 53-345 Wroclaw, Poland

$\square$ niki.derlukiewicz@ue.wroc.pl

\section{ANNA MEMPEL-ŚNIEŻYK}

Wroclaw University of Economics, Faculty of Economic Sciences, Department of Spatial Economy and Local Government Administration, Poland

$\square$ anna.sniezyk@ue.wroc.pl

\begin{abstract}
Motivation: The paper rises the issue of sustainable development in the context of challenges that present cities face. Development of innovative and sustainable economy is an aim for the whole society in the European Union. Three pillars of sustainable development: economic growth, environmental management and social inclusion are fundamental and occur across all economic sectors. Predominantly, they influence cities e.g. fast urbanization process, infrastructure, energy development as well as transportation. Cities in Europe are precursors of the transformation towards a low carbon and resource efficient economy. City authorities are planning and acting towards a more sustainable future characterized by investing in innovative, integrated technologies and services such as buildings, mobility, lighting and broadband communications.

Aim: The aim of the article is to present challenges facing European cities in the light of sustainable development. The paper explores trends in regional policy undertaken by the European Union relating to sustainable development. The first part outlines the global vision of present and future goals of sustainable development in the world. The next part focuses on the cities and challenges they face referring to sustainable and smart development.
\end{abstract}

Results: The conducted research shows sustainable development as still valid, important and topical. The research indicates that the structures of the EU are not the exclusively 
supportive and responsible for sustainable development in Europe. The entities such as cities play a very important role in achieving sustainability. Numerous European cities are still establishing programs integrating the energy, transport and ICT sectors in order to deliver more efficient services to their inhabitants. Finally, more and more cities are going to become smart in the nearest future.

Keywords: sustainable development; smart cities; innovation

JEL: R11; O18; O44

\section{Introduction}

At present, Europe is facing numerous challenges associated with exhaustible natural resources, climate change, aging population and increasing competition from other economies. The EU attempts to meet these challenges through supporting smart and sustainable growth.

To achieve the aim of the paper the first part outline the global vision of present and future goals of sustainable development. This part briefly introduces the importance of changes in the present socio-economic development. The next part of the article focuses on the cities and challenges they face relating to sustainable development. It is worth noting that European cities are precursors of the transformation towards a low carbon and resource efficient economy. They are already planning and acting towards a more sustainable future through innovative investments, integrated technologies and services such as heating/ cooling, mobility, lighting, broadband communications, innovative building and other utilities. Finally, the paper analyses the examples of smart cities.

The research methods adopted in the article include a review of domestic and international literature and reports as well as observation and case study.

\section{Literature review}

\subsection{Sustainable development - cities development context}

Sustainable development is one of the fundamental and most important objectives of the policy of the European Union. Sustainable development is the challenge that countries, cities, corporations, and organizations are facing presently (Kurniawan, 2012).

The European Union tries to meet the challenges of globalization and make the European economy one of the most competitive in the world through supporting smart and sustainable growth.

In early ' 90 sustainability initiatives were adopted by a lot of local governments and Campbell (1996, p. 301; Krueger \& Gibbs, 2007, p. 1) underlined in his work that 'in the battle of big public ideas, sustainability has won'. Sustainable growth means growth based on education, research and innovation, digital society as well as growth based on a more competitive low-carbon econ- 
omy that makes efficient, sustainable use of resources, protection of the environment (by reducing emissions and preventing biodiversity loss), capitalization on Europe's leadership in developing new green technologies and production methods as well as on the introduction of efficient smart electricity grids. There are a lot of programs and projects undertaken by European Union member's states in order to improve innovativeness and competitiveness of particular economies.

Over the last 50 years, the world has faced dramatic growth of its urban population. Currently European societies face many sustainability challenges from youth unemployment to ageing population, climate change, pollution, sustainable energy and migration. The notion of sustainability (see WCED (1987)) is not new and has as well supporters as critics, and it is considered in different aspects. For a long time and even now at some degree, there are people who believed that sustainable development is an oxymoron because it is impossible to reach development without polluting, but there are other people who have proven that it is possible to achieve economic growth in sustainable way (Velarde, 2011). Sustainable development is vague to define, as no universal definition exists. It has been identified as a wide solution to the existing urban planning issues, aiming at providing a better quality of life and advertises livable communities.

It should be emphasized that sustainable development recommends that the needs of the future can be meet depending on how well social (equity, participation, empowerment, social mobility), economic (services, household needs, industrial growth, agriculture growth) and environmental (biodiversity, natural resources, ecosystem integrity) objectives or needs are balanced. Very often needs are incompatible for instance, industrial growth may be in conflict with the protection of natural resources (Hopwood et al., 2005, p. 32).

Three pillars of sustainable development: economic growth, environmental management and social inclusion - are fundamental and occur across all sectors of development (Derlukiewicz, 2014, p 153). They influence cities e.g. fast urbanization process, infrastructure, energy development and use, water availability, as well as transportation (Girardet, 1999, p. 77) (scheme 1).

It is worth to add, according to Campbell (1996, p. 298), that there are three conflicts which resulting of three priorities in the context of sustainable development and are relate to as follow: planning green (environmental protection); growing cities (overall economic growth and efficiency); 'just cities' (social justice, economic opportunity, income equality).

In the context of sustainability one can find precise list of new goals in EU document: The 2030 Agenda for Sustainable Development. It is worth to note the importance of this document because it represents a commitment to eliminate poverty and achieve sustainable development by 2030 worldwide, ensuring that no one is left behind. The main issues of this document include such objectives as: no poverty; zero hunger; good health and well-being; quality education; gender equality; clean water and sanitation; affordable and clean energy; decent work and economic growth; industry, innovation and infrastructure; reduced 
inequalities; sustainable cities and communities; responsible consumption and production; climate action; life below water and life on land; peace, justice and strong institutions; and finally partnership for the goals (Eurostat, 2016, p. 139). One of mentioned priorities are sustainable cities, what is characterized in the next part of the article.

Furthermore, sustainable development concerns education improvement, research and innovation and creating an information society, where most of the people use information and communication technologies. The developing information society have to become able to constantly generate and adapt new technologies what influences the quality of their life, and allows them for improvement and new achievements in eco-economy (European Commission, 2010).

At current, scientists pay attention on large cities in the context of creation a global network in the world. Cities are the major source of the European economic activity and with high innovative potential have become a places for generating ideas (there are located scientific, educational and cultural institutions which act internationally), commerce, culture, science, productivity, social development etc. Cities are significant economic, political, and cultural centers and are important hub for international connections and communications. One can add that almost half of humanity lives in cities today, which account for about $80 \%$ of energy consumption and $75 \%$ of carbon emissions.

\subsection{Smart cities as an answer for challenges of sustainable development}

There are many different definitions of the smart city. In general, it is a city that performs well in six domains: smart economy, smart mobility, smart environment, smart people, smart living-cultural facilities, housing quality, health and safety issues, smart governance (European Smart Cities, 2017). The most of smart cities concentrate on the essential role of ICT in linking citywide services. According to Washburn and Sindhu (2009, p. 2): 'cities are becoming smarter, as governments, businesses, and communities increasingly rely on technology to overcome the challenges from rapid urbanization. What makes a 'smart city' is the combined use of software systems, server infrastructure, network infrastructure, and client devices to better connect seven critical city infrastructure components and services: city administration, education, healthcare, public safety, real estate, transportation, and utilities'. The evolution of the smart city idea is formed by a compound mix of technologies, social and economic features, governance engagements, and policy and business drivers. The implementation of the smart city concept, therefore, follows very varied paths depending on each city's specific policies, objectives, funding and scope (Manville, 2014, p. 21). 


\section{Methods}

In the paper the qualitative methods were used, in order to broaden the knowledge concerning the examined phenomena. In order to elaborate the basic information authors conducted the desk research and field research. In order to check the state of art of investigated issue and prepare the background for the empirical part of the paper the analysis of the literature on the subject was conducted. The desk research was supported by Google Scholar, Emerald, Scopus databases and website related to Smart Cities concept. It allowed to systematize the knowledge and definitions related to sustainable development in the context of challenges present cities have faced.

To achieve the aim of the article authors presented example of cities and their activities, as well as pointed out the benefits of common projects in the co0ntext of sustainable development. To present challenges which cities face as an result of ongoing changes in the modern economy, the authors used the method of case study. The case study was also helpful in the field of pointing out undertaken projects and initiatives by cities and implemented strategies by enterprises in the context of smart and sustainable growth.

\section{Results}

When it comes to smart cities Europe can be a good example for the rest of the world. European cities tend to be denser, have better public transport systems, larger commitment to cycling and walking, a stronger focus on sustainability and low-carbon solutions, and perhaps most importantly, the culture and citizens are more engaged in the journey towards more sustainable development and smarter cities (Cohen, 2014).

It is also important to mention the European Innovation Partnership on Smart Cities and Communities (EIP-SCC, 2013), that brings together cities, industry and citizens to improve urban life through more sustainable integrated solutions in the EU. Under this initiative some activities are supported e.g.: smart buildings and neighborhoods, smart supply and demand systems and services for better-informed citizens, sustainable urban mobility, smart and sustainable digital infrastructures (intelligent heating, cooling and lighting solutions) (see more: European Commission (2012)).

According to the IESE Cities in Motion Index 2016 (ICIM) ranking which examines all aspects that make up sustainability and quality of life in 181 key world cities, the world's smart cities are New York, London and Paris (Berrone \& Ricart, 2016, p. 23). By the study Mapping Smart Cities in the EU from 2014 the highest total number of smart cities are located in the UK, Spain and Italy; the countries with the highest proportion of Smart Cities are Italy, Austria, Denmark, Norway, Sweden, Estonia and Slovenia.

So far many European cities have established and implemented projects integrating the energy, transport and ICT sectors in order to deliver more efficient 
services to their inhabitants and to become smart cities. Very good examples of active cities in this field in Europe are also: Barcelona, Amsterdam, Helsinki, Copenhagen and Vienna (Manville, 2014, p. 80) (table 1).

More and more cities implement different projects to become smart and sustainable. For example, in 2012 there were 143 smart city projects of which 47 were located in Europe and 35 in North America. The projects were undertaken to implement smart technologies related to energy shortages, traffic congestion inadequate urban infrastructure, and some issues in health and education (Lee et al., 2014, p. 82).

It is worth mentioning that when implementing the projects many different barriers can occur. These barriers range from common financial deficiency to particular constraints, which depend on local socioeconomic, environmental and political characteristics of each city as well as characteristics of the project itself. One solution to anticipate barriers for an urban development project is to learn from previous similar experiences from best practices and applying their lessons learnt in the new projects (Mosannenzadeh et al, 2016, p. 28).

Another proposition connected with overcoming barriers and achieving a smart urban transformation for European cities is to focus on the urban sources of intelligent retrieval for quality their historical and cultural heritage (Vattano, 2013, pp. 112-116). In some examples, cities base on the promotion and strengthening of building restoration, another cities concentrate on technologies and systems of mobility, and some cities concentrate on space quality. For example, small city in Scotland was undertaken project of building houses which harmonize with the surrounding landscape, and at the same time the houses are at the forefront in terms of energy. Another example of city - Turin in Italy realized strategy based on building models of public-private partnerships and innovative engagement. S. Vattano (2013, pp. 112-116) analyzes sustainable development of cities such as Curitiba and Paredes, Turin and Genoa, mentions also Rotterdam South, Sao Paulo and underlines that 'not only large cities plan complex technological infrastructure but also medium size centers can be engine for growth through targeted interventions that improve the quality of life of citizens'. Referring to other examples of cities like London, Barcelona, Helsinki, Amsterdam, Paris and etc., which are pioneers of the transformation towards a low carbon and resource efficient economy in Europe. They are planning and acting for a more sustainable future characterized by investments in innovative, integrated technologies and services such as buildings, mobility, lighting and broadband communications. However, in Europe there also numerous cities that deal with many different problems like congestion, traffic jams, air pollution (smog), environmental degradation, communication problems and social exclusion.

It is worth mentioning that in implementing project many different barriers can occur. These barriers range from common financial deficiency to particular constraints, which depend on local socioeconomic, environmental and political 
characteristics of each city as well as characteristics of the project itself (Mosannenzadeh et al, 2016, p. 28).

Taking into account recent policy in Europe, the main challenges for the cities for forthcoming years are to become the diverse, cohesive and attractive cities and change into the green and healthy cities. These challenges can be reached for example through: reducing energy poverty and spatial exclusion, making mobility sustainable, inclusive and healthy, developing attractive open public places, developing social innovation, adapting the city's economic and social life to an ageing population, attracting the young and making places for children, approaching to environmental issues and energy efficiency in a holistic way, improving collaborative governance mechanisms dedicated to integrated planning and management, maximizing the use of city-wide data (European Commission, 2011, pp. 1-65).

As the result of the research conducted in Poland, Wroclaw turned out to be a Polish smart city. Wroclaw is noted as one of the top hundred most intelligent cities in the world - according to the IESE Cities in Motion Index 2017 report. Apart from Wroclaw, which took the 95th place in the ranking, Warsaw was also included. Unfortunately, these were only 2 cities from Poland which were included in that report.

The city of Wroclaw is an example of city, where many various initiatives and projects aimed at creating smart city are realized. In Wroclaw, most smart city projects relate to transport. There are about 20 projects and their aim is to increase mobility, that is, to move in a convenient, fast and safe manner, using the most modern technologies. The care for the natural environment is also very important. The most popular projects concern: Wroclaw City Bike, Wroclaw Electric Vehicle Charging System, Expansion of public transport hubs in Wroclaw, Urban Card - Wroclaw City Card or Intelligent Transport System. Of course these are not the only ones, because there are also some projects in other fields. About 11 smart city projects in Wroclaw are connected with city management and, above all, administration. Its purpose is to provide services tailored to the individual needs of residents. It aims to develop a creative economy by opening and sharing public information, as well as by removing barriers that the office itself creates. Among the smart city projects carried out in this area is Virtual Resident Advisor, e-council Software, Mobile Resident Assistant, Electronic Document Management, e-PUAP, Queue System and Sign Language Translator.

One of the very interesting projects worth presenting in the article is CityLab, which goal is to create areas in the urban space within which entrepreneurs, start-ups, scientists and consortia of these entities will be able to test their unique and unprecedented solutions in the public space. Currently, the priority is to study technologies that have an impact on the environment and health of residents, in other words related to transport and reduction of low emissions.

The city authorities are constantly taking steps to make the city live better. Unfortunately, there are still some problems in the city such as traffic jams, lack 
of parking places and the most serious problem as air pollution. So local authorities have still some challenges ahead.

\section{Conclusion}

In the light of the research results, it can be stated that cities are the key element for the sustainable development and this issue is constantly discussed. Ongoing changes concerning urbanization process confirm significant role of cities in achieving development in a sustainable way. As it results from the research the development of cities will determine the future economic, social and territorial development of the European Union. The research confirmed that cities play a crucial role as locomotives of the economy, as places of connectivity, creativity and innovation, and as centers of services for their surrounding areas. If the cities play a prime role in social and economic aspects worldwide and influence on the environment, it is easy to understand why cities are the key elements for the future (Zhuhadar et al, 2016).

The literature review confirms that cities, which are systems with people, energy flows, materials, services and financing, need to be explored in an integrated and global way to ensure smart and sustainable development. By challenges of sustainability which European cities are facing, they want to avoid negative impacts of economic development on the functioning ecosystems on which all life depends (Collins, 2017, p. 94). Cities gain greater control over their development and progression into the 21st century, they face a range of challenges and threats to sustainability in a variety of ways (Dirks et al., 2009, pp. 1-5). It is extremely important that cities are able to meet and overcome them. It is worth to remember that next to the economic challenges, cities have to meet expectations of residents. The answer for this expectations generates the smart cities. A smart city is a place where the traditional networks and services are made more proficient with the use of digital and telecommunication technologies, for the advantage of its inhabitants and businesses.

The research shows that smart city concept aims at solving different urban problems like: traffic, congestion, over-development, pressure on land, through ICT-based technology. Smart cities are intended to create a better, more sustainable city, where people's quality of life is higher, their environment more livable and their economic prospects stronger (Lee et al, 2014, p. 82). The idea of smart city is that investments in human and social capital, supported by the development of modern infrastructure, are the basis for sustainable economic development and the building blocks of high quality of life. The individual elements must complement each other and interact with each other. However, for it to succeed, it needs conscious and committed people.

During analysis author find out that the most common challenges for the cities are those connected with transforming them into green and healthy cities. It is crucial to implement actions that will help cities to achieve that. There is no one correct and proper way for smart and sustainable growth for cities. 
Examples from the Europe showed that each entity with using their own resources and potential and basing on others' experience should find their own way to meet present and forthcoming challenges. One can add that complex approach to future development of cities and strengthening of existing potential and connecting it with innovative and green technologies can result not only as smart development but also in many other benefits for cities and located their businesses.

Therefore, in the forthcoming years it will be necessary to conduct research in this issues to learn how cities deal with sustainability and if they continue to implement next projects and activities to build smart and sustainable economy in Europe.

There is also a need to answer the question how they deal with current problems which were mentioned in the paper and to find out if implemented projects and undertaken initiatives contributed to improvement in areas of tree main pillars of sustainability.

\section{References}

Berrone, P., \& Ricart, J.E. (2016). IESE cities in motion index 2016. Retrieved 01.02.2017 from http://www.iese.edu.

WCED. (1987). Report of the World Commission on Environment and Development: our common future. Retrieved 01.02.2017 from http://www. un-documents.net.

Campbell, S. (1996). Green cities, growing cities, just cities? Urban planning and the contradictions of sustainable development. Journal of the American Planning Association, 62(3). doi:10.1080/01944369608975696.

Cohen, B. (2014). The 10 smartest cities in Europe. Which European cities are doing the most innovative things with infrastructure, technology, and entrepreneurship? Retrieved 05.02.2015 form http://www.fastcoexist.com.

Collins, T.J. (2017). Review of the twenty-three-year evolution of the first university course in green chemistry: teaching future leaders how to create sustainable societies. Journal of Cleaner Production, 140. doi:10.1016/j. jclepro.2015.06.136.

Derlukiewicz, N. (2014). Development of smart and sustainable economy in the European Union. European Journal of Sustainable Development, 3(4). doi:10.14207/ejsd.2014.v3n4p151.

Dirks, S., Keeling, M., \& Dencik, J. (2009). How smart is your city? Helping cities measure progress. Retrieved 09.12.2016 from https://www-01.ibm.com.

European Commission. (2010). Europe 2020. A European strategy for smart, sustainable and inclusive growth. Retrieved 12.12.2016 from http://ec.europa.eu.

European Commission. (2012). Connecting smart and sustainable growth through smart specialization: a practical guide for ERDF managing authorities. Retrieved 10.02.2017 from http://ec.europa.eu. 
EIP-SCC. (2013). Strategic implementation plan. Retrieved 01.02.2017 from http://ec.europa.eu.

Eurostat. (2016). Sustainable development in the European Union: a statistical glance from the viewpoint of the un sustainable development goals. Luxembourg: Publications Office of the European Union. doi:10.2785/500875.

Girardet, H. (1999). Creating sustainable cities. Totnes-Devon: Green Books.

Hopwood, B., Mellor, M., \& O’Brien, G. (2005). Sustainable development: mapping different approaches. Sustainable Development, 13(1). doi:10.1002/ sd.244.

Krueger, R., \& Gibbs, D. (2007). The sustainable development paradox. Urban Political Economy in the United States and Europe. New York-London: Guilford Press.

Lee, J.H., Hancock, M.G., \& Hu, M.C. (2014). Towards an effective framework for building smart cities: lessons from Seoul and San Francisco. Technological Forecasting \& Social Change, 89. doi:10.1016/j.techfore.2013.08.033.

Manville, C. (2014). Mapping smart cities in the EU. Retrieved 01.02.2017 from http://www.europarl.europa.eu.

Mosannenzadeh, F., Bisello, A., Diamantini, C., Stellin, G., \& Vettorato, D. (2016). A case-based learning methodology to predict barriers to implementation of smart and sustainable urban energy projects. Cities, 60. doi:10.1016/j.cities.2016.07.007.

Vattano, S. (2013). European and Italian experience of smart cities: a model for the smart planning of city built, Techne, 5. doi:10.13128/Techne-12809.

Velarde, R. (2011). Sustainable development in developing countries by Rodrigo Velarde. Retrieved 03.02.2017 from http://sustainabilityandlaw.com.

Washburn, D., \& Sindhu, U. (2010). Helping CIOs understand 'smart city' initiatives. Retrieved 03.02.2017 from https://www.itworldcanada.com.

Kurniawan, J. (2012). Inclusive green growth policies tailored to real-world challenges. Retrieved 01.02.2017 from http://www.worldbank.org.

Zhuhadar, L., Thrasher, E., Marklin, S., \& Ordonez de Pablos, P. (2017). The next wave of innovation: review of smart cities intelligent operation systems. Journal of Computers in Human Behavior, 66. doi:10.1016/j.chb.2016.09.030.

European Smart Cities. (2017). Retrieved 03.02.2017 from http://www. smart-cities.eu.

\section{Acknowledgements}

Author contributions: authors have given an approval to the final version of the article. Authors contributed to this work equally.

Funding: this research was fully funded by the Wroclaw University of Economics

Note: the results of this study were presented at 9th International Conference on Applied Economics Contemporary Issues in Economy (June 22-23, Toruń, Poland). 


\section{Appendix}

Table 1.

Examples of smart solutions implemented in European cities

\begin{tabular}{|c|c|c|}
\hline City & Smart city solution & Impact \\
\hline Amsterdam & $\begin{array}{c}\text { climate street, smart building technology, local } \\
\text { integrated sustainability initiatives }\end{array}$ & $\begin{array}{l}\text { reduced energy consumption, inclusion, reduced } \\
\qquad \mathrm{CO}_{2}\end{array}$ \\
\hline Barcelona & $\begin{array}{l}\text { smart city lighting, smart parking, single access } \\
\text { points for government services, smart open } \\
\text { services platform, smart traffic flow system }\end{array}$ & $\begin{array}{l}\text { reduced energy consumption, reduced travel } \\
\text { to municipal offices, reduced } \mathrm{CO}_{2} \text {, safety }\end{array}$ \\
\hline Copenhagen & $\begin{array}{l}\text { smart cycling, integrated public transport, smart } \\
\text { open services platforms }\end{array}$ & $\begin{array}{l}\text { healthy living, } \mathrm{CO}_{2} \text { emissions reduction through } \\
\text { congestion reduction }\end{array}$ \\
\hline Helsinki & $\begin{array}{l}\text { smart open services platforms, integrated } \\
\text { multimodal transport, smart building technology }\end{array}$ & Reduced energy consumption, $\mathrm{CO}_{2}$ reduction \\
\hline London & $\begin{array}{c}\text { smart cycling plans, integrated multimodal } \\
\text { transport }\end{array}$ & $\begin{array}{l}\text { healthy living, } \mathrm{CO}_{2} \text { emissions reduction through } \\
\text { congestion reduction }\end{array}$ \\
\hline
\end{tabular}

Source: Own preparation based on Manville (2014, p. 38).

\section{Scheme 1 .}

Needs in three main domains of sustainable development

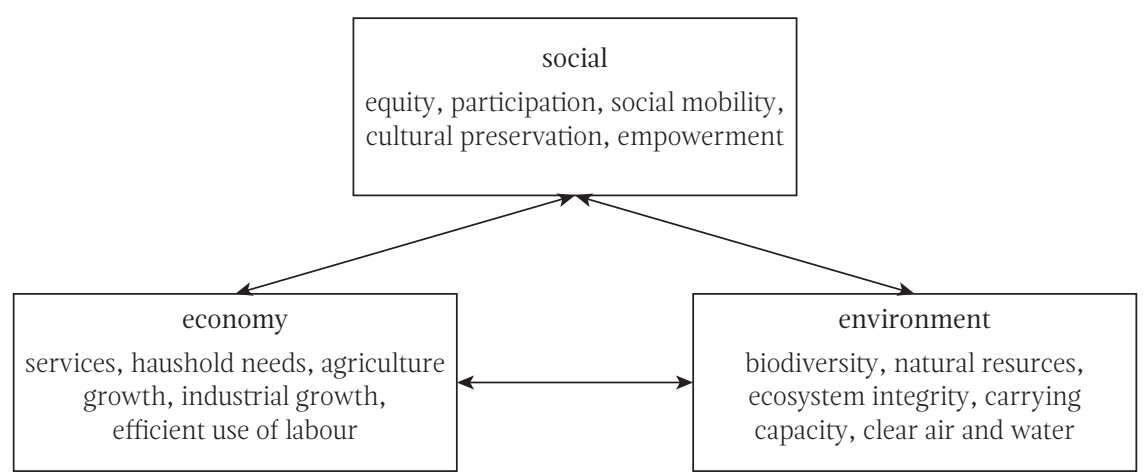

Source: Own preparation based on Campbell (1996, p. 298). 
